Fournal of Medical Genetics (1973). 10, 154.

\title{
Favism: Current Problems and Investigations
}

\section{E. BOTTINI}

National Research Council, Centre for Evolutionary Genetics, Department of Genetics, School of Science,
University of Rome and Department of Pediatrics, School of Medicine, University of Rome, Italy

Summary. Haemolytic favism is a severe, acute anaemia which occurs in glucose-6-phosphate dehydrogenase deficient individuals, usually following the ingestion of Vicia faba seeds. Current interest is focused on the nature of the active substances of Vicia faba and on the causes of the varying susceptibility among G6PD-deficient individuals to episodes of severe haemolysis.

The results of experiments in vitro favour the hypothesis that Vicia faba contains several active substances which may act in a synergistic way.

Red cell acid phosphatase and thalassaemia genes appear to play a remarkable role in conditioning the susceptibility to severe haemolysis in G6PD-deficient subjects.

In addition to erythrocyte enzymes and to enzymes which intervene in the absorption and metabolism of the active substances of Vicia faba, another field for future investigations may be that of plasma factors which influence the stability of reduced glutathione in the red cells.

Subjects with red blood cell (RBC) deficiency of G6PD may present episodes of acute haemolytic anaemia (haemolytic favism) after ingestion of Vicia $f a b a$ beans. The current interest in this severe anaemia is concerned first with the nature of the active substances of Vicia faba responsible for the haemolysis and secondly, with the causes of the considerable inter-individual variability in response to the active substances of Vicia faba in the presence of G6PD deficiency.

Haemolysis in these subjects is preceded by a fall in the level of RBC-reduced glutathione (GSH) (Panizon and Pujatti, 1958); although not yet proven, this is usually regarded as a cause-effect relationship. Experiments carried out in vitro have shown that Vicia faba juice or aqueous extract induces a fall of GSH in G6PD-deficient RBC similar to that induced by various drugs with haemolytic action (Mela and Perona, 1959; Walker and Bowman, 1960; Contu et al, 1961; Zacchello, Panizon, and Zanesco, 1964). From studies on the action of vicine and convicine aglycons* (Lin and Ling, 1962a, b, and c; Mager et al,

Received 24 April 1972.

* Vicine and convicine are $\beta$-glycosides occurring in broad beans. Their aglycon moieties are divicine and isouramil, respectively.
1965) on GSH in vitro, it was then suggested that the 'haemolytic principle' of Vicia faba could be identified with some of these substances. However, $\overrightarrow{\vec{O}}$ the glycosides vicine and convicine, both of which $\exists$ are present in Vicia faba, are inactive on GSH (Mager et al, 1965) and it is not known whether the relevant aglycons are present in the extracts of broad beans tested in vitro. A similar action on GSH by $\beta$-(3-4-dihydroxyphenyl) L-alanine (L- $\frac{0}{3}$ dopa) observed in some studies (Kosower and Kosower, 1967) has not been confirmed by Razin et al (1968) who suggested a synergistic action of this substance with the aglycon of divicine. More re- 을 cently (Beutler, 1970) it has been suggested that the $D$ active haemolytic principle is dopaquinone, produced from L-dopa through the action of tyrosinase. N Appropriate experiments in vivo (Gaetani et al, 1970) and clinical observations (Braham and Sarova- N Pinhas, 1971) have failed to provide any evidence in $\tilde{\omega}$ favour of the L-dopa hypothesis.

G6PD deficiency is the necessary condition fore the occurrence of haemolytic episodes but it is not, $\frac{\mathbb{D}}{8}$ by itself, the sufficient condition. It has been ? reported that the incidence of clinical favism in a 0 group of enzymopenic subjects taken at random was less than 30\% (Bernini et al, 1960). The action of $\cong$ 
some other genetically determined factor has been suggested by Sartori in 1959 on the basis of his clinical findings. Siniscalco et al in 1961 observed that the presence of thalassaemia trait makes G6PD-deficient individuals less liable to acute haemolysis due to Vicia faba. In 1966, Stamatoyannopoulos et al reported data showing the existence of an autosomal gene which favours the haemolytic episodes in subjects deficient in G6PD. More recently Beutler (1970) has suggested a polymorphism of tyrosinase; this would influence the rate of production of dopaquinone from L-dopa and in turn the susceptibility to haemolysis.

In the present article some recent results obtained by our group (Bottini et al, 1970b and 1971) are briefly reviewed; these contribute to the elucidation of the problems discussed.

\section{Materials and Methods}

An extract of Vicia faba in an organic solvent (methanol-chloroform $1: 1$ by volume) was fractionated (1) by partition in the two phases of a mixture of chloroformmethanol-water $(8: 4: 3)$ and (2) by paper ascending chromatography in a mixture of isopropanol $(46.7 \%)$, ethanol $(23.3 \%)$, formic acid $(2.5 \%)$, and water $(27.5 \%)$. The crude extract and its fractions were incubated in both aerobic and anaerobic conditions at $37^{\circ} \mathrm{C}$ either with a GSH solution, $0.005 \mathrm{M}$ in phosphate buffer $p \mathrm{H} 7 \cdot 4$ $(\mathrm{I}=0.1)$ with $0.02 \mathrm{M}$ EDTA, or with a suspension of RBC from G6PD-deficient male subjects. GSH assay was carried out according to the method of Beutler, Duron, and Kelly (1963).

The erythrocyte acid phosphatase* phenotype of 173 G6PD-deficient male subjects with a past history of haemolytic favism was determined by starch gel electrophoresis (Hopkinson et al, 1963). Sixty-nine of these subjects were collected from the population of Rome and 104 from that of Oristano district of Sardinia. The mean ages at the first haemolytic episode were 4 and 17 years respectively. Control groups of individuals from the same populations were also examined or were available from the literature.

\section{Results}

The experiments carried out with our extract and its fractions have shown the existence in Vicia faba

* Acid phosphatase is an SH-dependent erythrocyte enzyme with an electrophoretic polymorphism determined, in Caucasian populations, by three common codominant alleles $\left(\mathrm{PA}^{\mathrm{A}}, \mathrm{P}^{\mathrm{B}}, \mathbf{P C}\right)$ at an autosomal locus (Hopkinson, Spencer, and Harris, 1963). Correspondingly there are six phenotypes: $\mathrm{A}, \mathrm{B}, \mathrm{C}, \mathrm{BA}, \mathrm{CA}$ and $\mathrm{CB}$. In previous in-vitro investigations (Bottini and Modiano, 1964 and 1966; Bottini et al, 1967), we observed that under the action of oxidized glutathione or acetylphenylhydrazine, this enzyme undergoes some typical changes of its electrophoretic pattern, associated with striking decrease of its enzymatic activity. Moreover the various isozymatic fractions were found to have a different resistance to inactivation induced by those substances. Such findings in vitro prompted us to search for an association between the phenotype of RBC acid phosphatase and oxidative haemolysis.

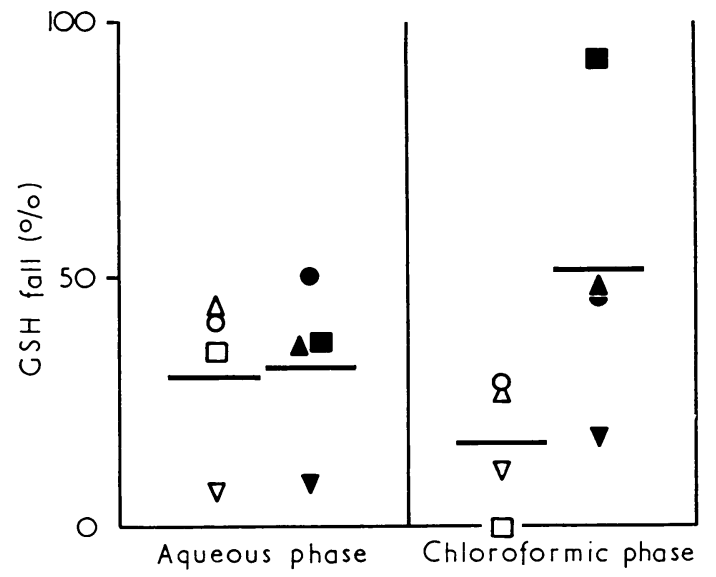

FIG. 1. The action of two fractions of a Vicia faba extract on the GSH of G6PD-deficient RBC.

The two phases obtained from a mixture of chloroform-methanolwater in which a certain amount of highly concentrated extract of Vicia faba had been dissolved, were divided into various fractions and dried at reduced pressure and low temperature.

The dry extract was dissolved with $0.5 \mathrm{ml}$ of ACD solution and $0.6 \mathrm{ml}$ of whole blood from a G6PD-deficient subject was added. After gentle mixing, this suspension was incubated at $37^{\circ} \mathrm{C}$ in air. At the same time another sample was prepared in the same manner and after shaking in $\mathrm{CO}$ current for nearly $5 \mathrm{~min}$, was incubated in $\mathrm{CO}$ atmosphere. The controls consisted of mixtures of blood and ACD solution incubated in air or in CO. After three hours of incubation, GSH was assayed in the RBC suspension. Four experiments, indicated in the figure by different symbols, were carried out. Each experiment included incubation of RBC in CO (white symbols) and in air (black symbols) with separate extracts from the aqueous and from the chloroformic phases. In each experiment two other samples of the same blood with ACD were incubated with APH either in the presence of air or of CO. In all cases CO almost totally suppressed the APH effect on RBC GSH.

In the ordinate GSH disappeared during incubation is expressed as a percentage of the value in controls incubated for the same period of time without extract. Both fractions are active on the GSH of G6Pd-deficient RBC: inhibition by $\mathrm{CO}$ is strong in the chloroformic phase activity but is much weaker in the aqueous phase activity.

The original data concerning these experiments are reported in Bottini et al (1970b).

of two substances (or classes of substances) which induce an in-vitro fall of GSH in aqueous solution and in G6PD-deficient intact red blood cells. The effect is very slight or absent on normal RBC (Bottini et al, 1970b). The results of a series of experiments carried out with fractions obtained by partition in the chloroform-methanol-water mixture are summarized in Fig. 1. One fraction acts upon the GSH of G6PD-deficient RBC better, or only, in aerobic conditions whereas the second shows the same activity in the presence and absence of oxygen.

Although less intense, activity on GSH similar to that of Vicia faba has also been observed in extracts obtained from Pisum sativum and some other vegetables.

In two groups of G6PD-deficient male subjects 
TABLE I

FREQUENCY OF PB ALLELE OF ERYTHROCYTE ACID PHOSPHATASE IN G6PD-DEFICIENT MALE SUBJECTS WITH A POSITIVE HISTORY OF HAEMOLYTIC FAVISM

\begin{tabular}{l|c|c|c}
\hline \multicolumn{1}{c|}{ Subjects } & $\begin{array}{c}\text { PB Allele } \\
\text { Proportion }\end{array}$ & $\begin{array}{c}\text { Total Number } \\
\text { of P Alleles }\end{array}$ & $p$ \\
\hline $\begin{array}{l}\text { Normal Romans } \\
\text { (Modiano } \text { et al, 1967) }\end{array}$ & 0.658 & 834 & $<0.01$ \\
$\begin{array}{c}\text { Roman males with } \\
\text { favism }\end{array}$ & 0.536 & 138 & $<0.01$ \\
$\begin{array}{c}\text { Sardinian control group } \\
\text { Sardinian males with } \\
\text { favism }\end{array}$ & 0.727 & 528 & $<0.05$ \\
$\begin{array}{c}\text { Sardinian G6PD- } \\
\text { deficient males } \\
\text { without favism }\end{array}$ & 0.759 & 58 & 208 \\
\hline
\end{tabular}

TABLE II

PROPORTIONS OF ERYTHROCYTE ACID PHOSPHATASE PHENOTYPES IN G6PD-DEFICIENT MALE SUBJECTS WITH A POSITIVE HISTORY OF HAEMOLYTIC FAVISM. INCIDENCE OF HAEMOLYSIS CALCULATED FOR ACID PHOSPHATASE PHENOTYPES

\begin{tabular}{|c|c|c|c|c|}
\hline \multirow[t]{2}{*}{ Subjects } & \multicolumn{3}{|c|}{$\begin{array}{c}\text { Acid Phosphatase Phenotype } \\
\text { Proportions }\end{array}$} & \multirow{2}{*}{$\begin{array}{c}\text { Total } \\
\text { Number } \\
\text { of } \\
\text { Subjects }\end{array}$} \\
\hline & $\mathbf{A}, \mathbf{C A}$, and $\mathbf{C}$ & $\mathrm{BA}$ and $\mathrm{CB}$ & B & \\
\hline $\begin{array}{l}\text { Romans } \\
\text { Normal (Modiano } \\
\text { et al, 1967) } \\
\text { Males with favism } \\
\text { Incidence of } \\
\text { haemolysis* }\end{array}$ & $\begin{array}{l}0.122 \\
0.203 \\
0.499\end{array}$ & $\begin{array}{l}0.439 \\
0.522 \\
0.357\end{array}$ & $\begin{array}{l}0.439 \\
0.275 \\
0.188\end{array}$ & $\begin{array}{r}417 \\
69\end{array}$ \\
\hline $\begin{array}{l}\text { Sardinians } \\
\text { Control group } \\
\text { Males with favism } \\
\text { Incidence of } \\
\text { haemolysis* }\end{array}$ & $\begin{array}{l}0.080 \\
0.192 \\
0.720\end{array}$ & $\begin{array}{l}0.386 \\
0 \cdot 404 \\
0.314\end{array}$ & $\begin{array}{l}0.534 \\
0.404 \\
\\
0.227\end{array}$ & $\begin{array}{l}264 \\
104\end{array}$ \\
\hline
\end{tabular}

* Assuming a mean incidence of 0.30 for favism among G6PDdeficient males and assuming that the distribution of acid phosphatase phenotypes in the whole group of G6PD-deficient males (favic and non-favic) is equal to that observed in the general population (Bottini et al, 1971), the incidence (I) of favism in a given acid phosphatase phenotype can be calculated according to the following formula:

$$
I=\frac{P_{f}}{\mathbf{P}_{\mathbf{g}}} \times 0.30
$$

where $P_{f}$ and $P_{g}$ are the proportions of the acid phosphatase phenotype in favic subjects and in the general population respectively.

The carriers of $\mathrm{P}^{\mathrm{B}}$ in a single dose (BA and $C B$ phenotypes) show an incidence of favism intermediate between carriers of $P B$ in double dose (B phenotype) and subjects carrying only $\mathrm{P}^{\mathrm{A}}$ or $\mathrm{P}^{\mathrm{C}}$ or both $(\mathrm{A}, \mathrm{C}$, and CA phenotypes).

with a past history of severe haemolytic favism a marked deficiency in $\mathrm{P}^{\mathrm{B}}$, corresponding to an increase in the proportions of both $\mathrm{P}^{\mathrm{A}}$ and $\mathrm{P}^{\mathrm{C}}$ alleles, was observed as compared to controls from the same population (Bottini et al, 1971; see Table I).

Assuming a mean incidence for favism of $30 \%$ among G6PD-deficient males, one can calculate that the incidence of haemolytic crisis is $\sim 60 \%$ for subjects of $\mathrm{A}$ and CA phenotype, $\sim 35 \%$ for $\mathrm{BA}$ and
CB subjects, and $\sim 20 \%$ for G6PD-deficient sub-D jects of phenotype $B$ (Table II).

\section{Discussion}

The findings reported above suggest that the factors which determine the extreme variability in the occurrence of severe episodes of haemolytic favism in G6PD-deficient subjects, may indeed ben manifold.

The existence of several active substances in $\bar{\circ}$ Vicia faba suggests a possible synergistic action in $\overrightarrow{\vec{\omega}}$ determining the haemolytic event. A variabilityo in the concentration of the various active substances could possibly depend both upon the variety of Vicia faba and upon seasonal conditions. The $\overrightarrow{0}$ interaction of the substances with the genotypic ${ }^{\text {v }}$ characteristics and the physiological status of G6PD- $\vec{T}$ deficient individuals could explain the considerable ${ }_{0}^{+}$ variability in the response to Vicia faba observed ${ }^{3}$ both among different individuals and in the same $\vec{c}$ individual on different occasions. It is also interest- $-\frac{5}{F}$ ing that an action on GSH, although less intense, has ${ }^{\mathbb{}}$ been observed in extracts from other vegetables $\vec{\theta}$ currently used in human alimentation. The ob-ct servation brings to mind the definition of 'vegetable disease' given to favism more than a century ago (Minà la Grua, 1856). Haemolytic crises following the ingestion of vegetables other than Vicia faba are not exceptional in the experience of the author.

Two alleles $\left(\mathrm{P}^{\mathrm{A}}\right.$ and $\left.\mathrm{P}^{\mathrm{C}}\right)$ of a gene coding for an intra-erythrocytic enzyme with electrophoretic polymorphism appear to play a fairly remarkable role in bringing about severe haemolytic favism, whereas thalassaemia seems to have a protective role. It is known that several other erythrocyte enzymes show genetic polymorphism and it is conceivable that the variability of the metabolic activity of RBC may be connected with these polymorphisms. There is therefore the possibility of associations between haemolysis and the phenotypes of 0 several RBC proteins.

This, of course, does not exclude the possibility $\frac{7}{0}$ that extra-erythrocytic factors may have an important role in conditioning susceptibility to haemo- $N$ lytic favism. In addition to enzymes concerned in $N$ the absorption and metabolism of the active sub- N stances of Vicia faba, plasma factors which influence the stability of GSH in RBC may have some importance. It is known that such factors do exist $\stackrel{\circ}{=}$ (Jocelyn, 1960; Bottini et al, 1970a) but up to now $\stackrel{\infty}{\Phi}$ little attention has been paid to their possible role in physiological and pathological conditions.

In 1971, Sartori reconsidered his theory on the genetics of favism. He investigated a general form 
of 'favism' which apart from 'haemolytic favism' also includes a form 'without haemolysis'. The symptoms of 'favism without haemolysis' are those referred to as 'favism minor' in the old medical literature (mild headache, uneasiness, weakness, vomiting, and dizziness). According to Sartori's theory, the susceptibility to these symptoms (which follow the ingestion of Vicia faba beans or the inhalation of pollen) is determined by an autosomal recessive factor. The additional occurrence of G6PD deficiency (X-linked factor) would predispose to severe haemolytic crises ('haemolytic favism').

In our clinic we have only been able to study patients with haemolytic favism. The investigation of any possible association between 'favism minor' and the phenotype of erythrocyte acid phosphatase (and possibly of other proteins) would be of great interest. However, clear and workable definitions of the set of clinical and laboratory parameters which represent the necessary and sufficient conditions for the confirmation of the diagnosis of 'favism minor', are important preliminary requisites for any further investigation. Moreover, 'favism without haemolysis' is not observed in other Italian populations who eat large quantities of broad beans, but do not show G6PD deficiency. Therefore if one accepts Professor Sartori's hypothesis of a 'favism' independent from G6PD deficiency which is determined by a recessive autosomal factor, one must assume that this is a factor much more common in Sardinians than in other Italian populations.

\section{REFERENCES}

Bernini, L., Carcassi, U., Latte, B., Motulsky, A. G., Romei, L., and Siniscalco, M. (1960). Indagini genetiche sul la predisposizione al favismo. III : Distribuzione delle frequenze geniche per il locus $\mathrm{Gd}$ in Sardegna-Interazione con la malaria e la talassemia al livel lo popolazionistico. Atti della Accademia Nazionale dei Lincei. Rendiconti (Classe di Scienze fisiche, matematiche e naturali) 29, 115-125.

Beutler, E. (1970). L-dopa and favism. Blood, 36, 523-525.

Beutler, E., Duron, O., and Kelly, B. M. (1963). Improved method for the determination of blood glutathione. Fournal Laboratory and Clinical Medicine, 61, 882-888.

Bottini, E., Lucarelli, P., Agostino, R., Palmarino, R., Businco, L., and Antognoni, G. (1971). Favism: association with erythrocvte acid phosphatase phenotype. Science, 171, 409-411.

Bottini, E., Lucarelli, P., Spennati, G. F., Businco, L., and Cocciante, G. (1970a). Oxidizing action of neonatal and maternal plasma on reduced glutathione in vitro. Biologia Neonatorums, 15, 211-216.

Bottini, E., Lucarelli, P., Spennati, G. F., Businco, L., and Palmarino, $R$. (1970b). Presence in Vicia faba of different substances with activity in vitro on $\mathrm{Gd}(-)$ Med red blood cell reduced glutathione. Clinica Chimica Acta, 30, 831-834.

Bottini, E. and Modiano, G. (1964). Effect of oxidized glutathione on human red cell acid phosphatases. Biochemical and Biophysical Research Communications, 17, 260-264.
Bottini, E. and Modiano, G. (1966). On the effect of oxidized glutathione and acetylphenylhydrazine on red cell acid phosphatase. Blood, 27, 281-282.

Bottini, E., Modiano, G., Businco, L., Filippi, G., and Santo lamazza, C. (1967). Differential effect of oxidized glutathione or acetylphenylhydrazine on individual electrophoretic components of red cell acid phosphatases. Experientia, 23, 107-109.

Braham, J. and Sarova-Pinhas, I. (1971). Letter to the Editor. Blood, 37, 744.

Contu, L., Pitzus, F., Lenzerini, L., and Marcolongo, R. (1961). Inibizione in vitro del GSH eritrocitario da parte di estratti di fave. Rassegna di Fisiopatologia Clinica e Terapeutica, 33, 42-51.

Gaetani, G., Salvidio, E., Pannacciulli, I., Ajmar, F., and Paravidino, G. (1970). Absence of haemolytic effects of L-Dopa on transfused G-6-PD-deficient erythrocytes. Experientia, 26, 785-786.

Hopkinson, D. A., Spencer, N., and Harris, H. (1963). Red cell acid phosphatase variants: a new human polymorphism. Nature, 199, 969--971.

Jocelyn, P. C. (1960). The effect of some protein solutions on the oxidation of glutathione in oxygenated erythrocytes. Biochemical Fournal, 77, 368-380.

Kosower, N. S. and Kosower, E. M. (1967). Does 3,4-dihydroxyphenylalanine play a part in favism? Nature, 215, 285-286.

Lin, J. Y. and Ling, K. H. (1962a). Studies on favism. I: Isolation of an active principle from Fava beans (Vicia faba). fournal of the Formosan Medical Association, 61, 484-489.

Lin, J. Y. and Ling, K. H. (1962b). Studies on favism. II: Studies on the physiological activities of vicine in vivo. Fournal of the Formosan Medical Association, 61, 490-494.

Lin, J. Y. and Ling, K. H. (1962c). Studies on favism. III: Studies on the physiological activities of vicine in vitro. Fournal of the Formosan Medical Association, 61, 579-583.

Mager, J., Glaser, G., Razin, A., Izak, G., Bien, S., and Noam, M. (1965). Metabolic effects of pyrimidines derived from fava bean glycosides on human erythrocytes deficient in glucose-6-phosphate dehydrogenase. Riochemical and Biophysical Research Communications, 20, 235-240.

Mela, C. and Perona, G. P. (1959). Sulla resistenza in vitro del glutatione ridotto eritrocitario al succo di fave fresche. Bollettino della Società Italiana di Biologia Sperimentale, 35, 146-148.

Minà la Grua, A. (1856). Cited in Il Favismo by G. Sansone, A. M. Piga, and G. Segni, p. 203. Minerva Medica, Turin, 1958.

Modiano, G., Filippi, G., Brunelli, F., Frattaroli, W., and Siniscalco, M. (1967). Studies on red cell acid phosphatases in Sardinia and Rome. Absence of correlation with past malarial morbidity. Acta Genetica et Statistica Medica, 17, 17-28.

Panizon, F. and Pujatti, G. (1958). Studio sul glutatione eritrocitario nel favismo. Acta Paediatrica Latina, 11, 71-80.

Razin, A., Hershko, A., Glaser, G., and Mager, J. (1968). The oxidant effect of isouramil on red cell glutathione and its synergistic enhancement by ascorbic acid or 3,4-dihydroxyphenylalanine. Israel fournal of Medical Sciences, 4, 852-857.

Sartori, E. (1959). Teoria genetica della diatesi fabica e della diatesi idiosincrasico-iperemolitica. Studi Sassaresi, 37, 11-18.

Sartori, E. (1971). On the pathogenesis of favism. Fournal of Medical Genetics, 8, 462-467.

Siniscalco, M., Bernini, L., Latte, B., and Motulsky, A. G. (1961). Favism and thalassaemia in Sardinia and their relationship to malaria. Nature, 190, 1179-1180.

Stamatoyannopoulos, G., Fraser, G. R., Motulsky, A. G., Fessas, Ph., Akrivakis, A., and Papayannopoulou, T. (1966). On the familial predisposition to favism. American fournal of Human Genetics, 18, 253-263.

Walker, D. G. and Bowman, J. E. (1960). In vitro effect of Vicia faba extracts upon reduced glutathione of erythrocytes. Proceedings of the Society for Experimental Biology and Medicine, 103, 476-477.

Zacchello, F., Panizon, F., and Zanesco, L. (1964). Primachina e fave. II: Effetti in vitro sul glutatione eritrocitario e sulla metemoglobina. Acta Paediatrica Latina, 17, 173-181. 